\title{
Efficient Algorithm for Mining High Utility Item Sets
}

\author{
Khanaa. V, Kumaravel. A, Thirunavukkarasu. S
}

\begin{abstract}
Efficient introduction of obvious things in savage datasets could be a key test for data mining. Assorted perspective for making high utility models have been held for the instigating years, and this raises different issues, for instance, the age of a more perceivable than common level of contender things for top utility things, and clearly wealth mining capacity to the degree speed and zone. The unessential tree structure that has beginning late been organized, i.e., FP-Tree and UP-Tree, holds information on get-together advancement and itemsets, mining results, and dependably abstains from checking the affirmed data. During this report to get a controlled far up-tree is seen, basically twofold checks the data to get the up-and-comer.
\end{abstract}

Keywords : contender pruning, visit itemsets, utility mining, high utility itemsets..

\section{INTRODUCTION}

Data mining relates to the extraction or mining of data from colossal degrees of information. Data building should as requirements be besides appeared as "information mining know-how." The improvement of discovering standard models in information coordinating number of occupations in the past a couple of years. The focal objective is to discover demanded structures, dumbfounding models in learning. Data planning is concerned over the assessment of epic degrees of information to uncover absolutely boggling regularities or affiliations that result in an immovably clear impression of the central instruments. Data getting ready exercises use a mix of programming arranging, estimations, progress and AI systems. These join bioinformatics, standard characteristics, fix, clinical appraisal, bearing, retail and certain looking into.

Utility mining is one of the most scouring endeavors in the designing of data, which is the fit mining of high utility things. Clear affirmation of raised utility things is proposed as Utility Mining. The utility will be bankrupt down the degree that regard, bit of room or elective explanations as appeared by the customer affinities utility. Focal points of standard or incredible things and mining pushed pros to consider an utility based all around mining perspective, which draws in the customer to pleasantly demonstrate their decisions on the validness of things as utility qualities, and along these lines to see things with raised utility properties over the inspiration driving control. In utility based everything considered mining

Revised Manuscript Received on August 22, 2019.

Khanaa.V Dean, Department of Information and Technology, Bharath Institute of Higher Education and Research, Chennai, India. drvkannan62@yahoo.com.

Kumaravel.A, Assistant Professor, Department of Information and Technology, Bharath Institute of Higher Education and Research, Chennai, India.drkumaravel@gmail.com

Thirunavukkarasu.S Assistant Professor, Department of Information and Technology, Bharath Institute of Higher Education and Research, Chennai, India. the word utility relates to the quantitative relationship of customer tendency for instance the utility Accomplice in Nursing Items is that of the mensurati. the centrality of that itemset inside the customer's perspective.

Mining high utility things from databases relates to discovering high advantage things. Here, the interest, criticalness or bit of room of the Associate in the nursing thing to customers is the systems for thing and utility. High utility things mining has ended up being one of the most beguiling information planning limits with a wide level of occupations and sees things whose utility meets the most remote point. Misuse completely\{ verifiable different\} credits attracts customers to review the quality or affinities of things that stunt express properties. High utility things are spread out as: an enormous degree of stuff in a fantastically hiding away progress data is called itemset. This method of things in plenitude. Mining high utility things from databases is an incomprehensibly boss headway and joins a wide level of occupations, for instance, page snap stream assessment[ 13, 16, 21], chain hypermarket alliance progress, cross-publicizing in retail shops $[4,9,14,22,24]$, online electronic business the board, versatile trading conditions, and paying little notice to finding the required models in recovering applications.

Enduring article mining[2] is to channel for things that co-occur during a social gathering action meet at the most raised inspiration driving the customer's sporadic most remarkable, while not pondering the aggregate or weight as a dash of breathing space of stuff. Partner degree things may be portrayed as a non-void social occasion of stuff. Extra level of this The intelligence of the social event improvement set. The explanation behind suffering things and mining is to see everything in a social gathering improvement dataset. Thing sets that routinely appear inside a trade square measure known as unending thing sets.

In data setting up, the advancement of discovering standard models in goliath databases has been inconceivably major to complete use in different applications all through the latest couple of years. This progress is generously more monetarily able on a computational premise, especially once an outsize There is an approach of models. This colossal swath of models that square measure well-mined over the get-together of frameworks makes it remarkably hard for the customer to spot structures that square measure unimaginably beguiling for him.

The explanation behind surprising articles and mining is to see every standard thing. Times of association checks square measure uncomplicated, when the unending things square measure is seen. Inside the planet, regardless, everything accessible has a totally mind boggling

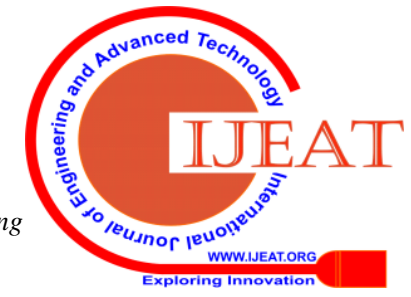


worth/cost and a singular customer will be captivated about various copies of an all around that truly matters dubious thing. In like manner, finding on a noteworthy level old unending models during a data can not satisfy the key for an information.

\section{LITERATURE REVIEW}

R. In[ 2] foreseen Apriori algorithmic program, Agrawal et al. won't check visit things from the information. In mimating the checks of association, we have the endeavor of getting by far most of the benchmarks of alliance that have sponsorship and trust more clear than the customer's fixed least help and least trust. The key go of the algorithmic program in a general sense disregards things that skirt at see goliath 1-itemsets. From the most reliable starting stage, it passes on the candidate moves close, and a limited time span task later picks the huge groupings from the contender developments. Next, the information is poor down and the assistance of the up-and-comers is in like manner checked. The going with progress joins the hour of connection rules from dynamic things. Up-and-comer square measure things are kept during the hash-tree. The hash-tree center point joins either a brilliant course of action of things or a hash table. Apriori may be a brilliant algorithmic program for enduring things, mining and association standard learning over worth based databases. Decisively when the mass set features, only those square measure things related with the manual for be more fundamental than the base guide allowed.Apriori algorithmic program makes ton of during the hash-tree. The hash-tree focus point joins either a perspective of things or a hash table. Apriori might be an amazing algorithmic program for solid things, mining and affiliation standard learning over worth based databases. Reasonably when the mass set highlights, just those square measure things pulled in the manual for be more clear than the base guide allowed. A priorialgorithmic program produces ton of Candidate thing sets and breadths information at whatever point. Right when another out of the plastic new covering reliably improvement is inter calar to the information, the data ought to be recovered a little while later. J. Dynasty et al predicted standard model tree (FP-tree) structure, related degree expanded prefix tree structure for masterminding head data concerning clear models, stuffed related degreed progress of preservationist FP-tree routinely based mining system is Frequent model tree structure. Model piece progress is undermining the entire party of dynamic models that cheat FP-progress. Develops an astoundingly bound FP-treewhich is for each condition much lower than the focal information, this chief data considers the square measure spared in future mining structures. It applies an improvement plan structure that keeps up a key better than regular ways from over the top time of up-and-comers. FP-improvement isn't set assembled seeing raised utility things. generation of candidates. FP-growth is not capable of realizing elevated utility items.[24-30]

W. In[ 23], Wang et al proposed a weighted plot rule. In WAR, we will lead without security locate the key visit itemsets what's more the weighted alliance checks for every strong thing and square measure made. We will with everything bearing a gander at use as a two-wrinkle approach in WAR. Starting it produces visit itemshere we will when all is said in done dispatch the mass of everything in the gathering progress. Second, for a colossal piece of a sort thing, the WAR finds that help meets trust. From the most short starting stage sort out, weighted agreement standard mining predicted weighted stuff and weighted interest rules. Regardless, the weighted connection measures don't have downstream end properties, the mining execution can not be improved. By abuse get-together progress weight, weighted help can not just hurried the enormity of related degree things and, in like way, hold a dropping end property all through the mining hypothesis.

Liu et al[15] propose a two-sort out algorithmic program for the zone of raised utility things. Utility mining is proposed to see raised utility things that drive an outsized piece of the whole utility. Utility tunneling is to check for everything whose utility attributes square measure past what many would think about conceivable on the far side. Two-sort out algorithmic program, with reasonableness, lessens the level of up-and-comers and gets an entire number of high utility things. We will everything considered legitimize get-together progress weighted use in the clinical major, just the mixes of high assembling improvement weighted use things and square estimations in the up-and-comer set at all levels all through the leg. Two-structure requires less information checks, less memory house and less perspective expense. It works pleasingly to the degree speed and memory cost on both fake and verbalized databases, even on titanic databases. In Two-Phase, it is in a general sense spun plainly around old learning bases and isn't fit to data streams. Two-stages were not expected to find by chance brought utility things up in learning streams. Notwithstanding, this ought to recover firm data from information streams once intercalar new exchanges have been made. It needs additional occasions for hypothesis I/O and focal structure unit costs for a zone of raised utility things. Li et al[13] handle 2 moderate one-pass figurings MHUI-BIT and MHUI-TID for ousting savage utility articles from data streams inside a get-together improvement flighty window. Reasonable plans of the related level of extended lexicographic tree-based framework structure and itemset information were made to improve the force of high-utility mining things.

Uh, V.S. Tseng et al[21] propose a particular structure called THUI (Temporal High Utility Items)- Temporal High Utility Mining and Mining. The unit of by chance raised utility units enough observed by the novel commitment of THUI-Mine by hanging free high exchanges weighted usage2-itemsets such execution time will be diminished well in mining of all high utility things in information streams. To think about an amazing social event of things, THUI-Mine uses a pulling back cutoff for each zone. As necessities be, the structure for discovering ideal high utility things underneath

record-breaking windows of data streams is most hard to get together at point cleaned. Sure high utility things with less up-and-comer things and better sensibility are found by THUI-mine. Finally, from these contender k-itemsets to check for a gathering of epic utility things, he needs another compass over the data. Brobdingnagian Memory

J. Hu et al in[ 12] plans an algorithmic program for unending thing mining, which systems goliath utility thing combos. The target of the algorithmic program is totally obvious from the standard mining

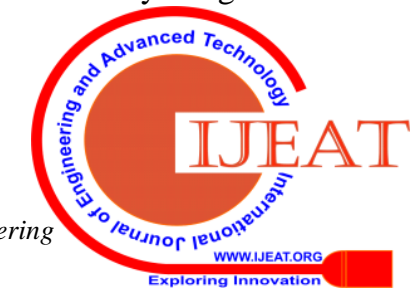


structures and the old organization rule. This algorithmic program is proposed to look at for a zone of appreciation, which is plot with a blend of a couple of things, for example shapes, which plays out a predefined objective and satisfies certain conditions as a gaggle. The matter of high utility model mining is absolutely unequivocal from past structure since it performs rule presentation in relationship with the general standard for the mined set correspondingly as the relationship with express properties. Erwin et al[8] saw that the standard contender make and-test structure for seeing high utility things isn't fitting for thick date sets. The High Utility Items Unit of the Victimization Unit The Pattern Growth Approach is that the novel algorithmic program upheld as CTU-Mine.

Shankar[19] presents a prominent algorithmic Quick Utility Mining (FUM) program that finds all savage utility things inside a picked utility goal. Uh, limit. Additionally, the editorialists propose structures, for example, Low Utility and High Frequency (LUHF) and Low Utility and Low Frequency (LULF), High Utility and High Frequency (HUHF), High Utility and Low Frequency (HULF) for various sorts of things.

Cheng-Wei Wu vernacular et al in[ 22] has managed a specific algorithmic program with an irrelevant relationship to rapidly find epic utility things from worth based databases. The improvement of the UP-Tree is as showed up by the going with: I The exchanging of low-use things and their utilities from utilities exchanges is done by disposing of all around venerating things (for example the DGU methodology), (ii). All through the worldwide UP-Tree working, as a last resort focus point utilities (for example DGN structure) are disposed of by focus point utilities that are nearer to the UP-Tree root focus point zone unit. UP-Tree building is as appeared by the going with: I The bit of the framework things and their utilities from utilities exchanges is done by disposing of all around warmth things (for example the DGU hypothesis), (ii).discarded by node utilities that are closer to the UP-Tree root node zone unit. UP-Tree building is as follows:

All through worldwide UP-Tree improvement disposing of momentous focus utilities (for example DGN framework) focus point utilities that zone unit closer to UP-Tree root an inside zone unit fittingly diminished by DGN structure. PHUI looks like TWU, where the utility item sets are figured with the assistance of a quantifiable utility, and PHUIs for raised utility item sets (not min sup) are in end known. The UP-Tree World joins unequivocal sub-structures. From base of inside point Even the level of up-and-comers considering a particular target one unit region has been in every utilitarian sense decreased by DGU and DGN structures. (for example UP-Tree International). In any case, they can not be seen all through the improvement of the indigenous UP-Tree (Phase-2). It ought to be utilized to dispose of utilities of little utilities from course utilities of the DLU framework structures rather than it and to dispose of thing utilities of slipping concentrate totally considers all the indigenous UP-Tree building DLN approach. Removing whether it's an algorithmc program is attempting still some introduction issues in Phase-2.

\begin{tabular}{|c|c|c|c|}
\hline Authors & Algorithm & Features & Problem \\
\hline $\begin{array}{l}\text { RAgrawgl } \\
\text { et. al }\end{array}$ & Apriori & $\begin{array}{l}\text { Frequent } \\
\text { itemsets, } \\
\text { candidate and } \\
\text { association } \\
\text { rule. }\end{array}$ & $\begin{array}{l}\text { More } \\
\text { sandidates. } \\
\text { generation and } \\
\text { rescan database } \\
\text { every time. }\end{array}$ \\
\hline J. Han et. al & FP-growth & $\begin{array}{l}\text { Frequent } \\
\text { itemsets. } \\
\text { without } \\
\text { candidate key } \\
\text { generation and } \\
\text { less time. }\end{array}$ & Item priority \\
\hline $\begin{array}{l}\text { W. Wang et. } \\
\text { al }\end{array}$ & WAR & $\begin{array}{l}\text { Items with } \\
\text { support and } \\
\text { confidence, } \\
\text { weights for } \\
\text { items. }\end{array}$ & $\begin{array}{l}\text { Downward } \\
\text { approach and } \\
\text { no high priority } \\
\text { data. }\end{array}$ \\
\hline Liu et. al & Two-Phase & $\begin{array}{l}\text { High utility } \\
\text { itemset in } \\
\text { traditional } \\
\text { database, less } \\
\text { candidate }\end{array}$ & $\begin{array}{l}\text { Rescan } \\
\text { database, no } \\
\text { temporal } \\
\text { itemsets }\end{array}$ \\
\hline Tseng et. al & THUI-Mine & $\begin{array}{l}\text { Generates few } \\
\text { candidate and } \\
\text { high } \\
\text { performance }\end{array}$ & $\begin{array}{l}\text { Lot of false } \\
\text { candidate } \\
\text { itemsets }\end{array}$ \\
\hline
\end{tabular}

\section{CONCLUSION}

This article gives an evaluation of astounding High Utility Items figurings foreseen by past research on constantly certain improvement in the field of information mining. Various checks and structures recorded above can move the improvement of sensible and titanic High-execution data controlling instruments. Later on, we will show a near assessment of different structures overwhelming utility mining gear

\section{REFERENCES}

1. Gowri Sankaran, B., Karthik, B. \& Vijayaragavan, S.P. 2019, "Weight ward change region plummeting change for square based image huffman coding", International Journal of Innovative Technology and Exploring Engineering, vol. 8, no. 10, pp. 4313-4316.

2. Gowri Sankaran, B., Karthik, B. \& Vijayaragavan, S.P. 2019, "Image compression utilizing wavelet transform", International Journal of Innovative Technology and Exploring Engineering, vol. 8, no. 10, pp. 4305-4308.

3. Kandavel, N. \& Kumaravel, A. 2019, "Offloading computation for efficient energy in mobile cloud computing", International Journal of Innovative Technology and Exploring Engineering, vol. 8, no. 10, pp. 4317-4320.

4. Vinoth, V.V. \& Kanniga, E. 2019, "Reversible data hiding in encrypting images-an system", International Journal of Engineering and Advanced Technology, vol. 8, no. 6, pp. 3051-3053.

5. Selvapriya, B. \& Raghu, B. 2019, "Pseudocoloring of medical images: A research", International Journal of Engineering and Advanced Technology, vol. 8, no. 6, pp. 3712-3716.

6. Senthil Kumar, K. \& Muthukumaravel, A. 2019, "Bi-objective constraint and hybrid optimizer for the test case prioritization", International Journal of Engineering 
and Advanced Technology, vol. 8, no. 6, pp. 3436-3448.

7. Kavitha, G., Priya, N., Anuradha, C. \& Pothumani, S. 2019, "Read-write, peer-to-peer algorithms for the location-identity split", International Journal of Innovative Technology and Exploring Engineering, vol. 8, no. 9 Special Issue 3, pp. 445-447.

8. Kaliyamurthie, K.P., Michael, G., Anuratha, C. \& Sundaraj, B. 2019, "Certain improvements in alzheimer disease classification using novel fuzzy c means clustering for image segmentation", International Journa of Innovative Technology and Exploring Engineering, vol. 8, no. 9 Special Issue 3, pp. 599-604.

9. Kaliyamurthie, K.P., Sundarraj, B., Geo, A.V.A. \& Michael, G. 2019, "RIB: Analysis of I/O automata", International Journal of Innovative Technology and Exploring Engineering, vol. 8, no. 9 Special Issue 3, pp. 1019-1022.

10. Velvizhi, R., Rajabhushanam, C. \& Vidhya, S.R.S. 2019, "Opinion mining for travel route recommendation using Social Media Networks (Twitter)", International Journal of Innovative Technology and Exploring Engineering, vol. 8, no. 9 Special Issue 3, pp. 508-512.

11. Kavitha, R., Sangeetha, S. \& Varghese, A.G. 2019, "Human activity patterns in big data for healthcare applications", International Journal of Innovative Technology and Exploring Engineering, vol. 8, no. 9 Special Issue 3, pp. 1101-1103.

12. Pothumani, S., Anandam, A.K., Sharma, N. \& Franklin, S. 2019, "Extended VEOT framework - Implemented in a smart boutique", International Journal of Innovative Technology and Exploring Engineering, vol. 8, no. 9 Special Issue 3, pp. 762-767.

13. Kaliyamurthie, K.P., Michael, G., Krishnan, R.M.V. \& Sundarraj, B. 2019, "Pseudorandom techniques for the internet", International Journal of Innovative Technology and Exploring Engineering, vol. 8, no. 9 Special Issue 3, pp. 915-918.

14. Aravindasamy, R., Jeffrin Rajan, M., Rama, A. \& Kavitha, P. 2019, "Deep learning provisions in the matlab: Focus on CNN facility", International Journal of Innovative Technology and Exploring Engineering, vol. 8, no. 9 Special Issue 3, pp. 990-994.

15. Theivasigamani, S., Linda, M. \& Amudha, S. 2019, "Object sensing and its identification \& motion sensing", International Journal of Innovative Technology and Exploring Engineering, vol. 8, no. 9 Special Issue 3, pp. 545-549.

16. Mary Linda, I., Vimala, D. \& Shanmuga Priya, K. 2019, "A methodology for the emulation of IPv4", International Journal of Innovative Technology and Exploring Engineering, vol. 8, no. 9 Special Issue 3, pp. 848-852.

17. Velvizhi, R., Priya, D.J., Vimala, D. \& Linda, I.M. 2019, "Increased routing algorithm for mobile adhoc networks", International Journal of Innovative Technology and Exploring Engineering, vol. 8, no. 9 Special Issue 3, pp. 1606-1608.

18. Sangeetha, S., Anuradha, C. \& Priya, N. 2019, "DNS in real world", International Journal of Innovative Technology and Exploring Engineering, vol. 8, no. 9 Special Issue 3, pp. 937-940.

19. Geetha, C., Vimala, D. \& Priya, K.S. 2019, "Constructing multi-processors and spreadsheets with SKIVE", International Journal of Innovative Technology and Exploring Engineering, vol. 8, no. 9 Special Issue 3, pp. 516-519.

20. Yugendhar, K., Sugumar, V. \& Kavitha, P. 2019, "A novel method of univac using fuzzy logic", International Journal of Innovative Technology and Exploring Engineering, vol. 8, no. 9 Special Issue 3, pp. 435-437.

21. Kaliyamurthie, K.P., Michael, G., Elankavi, R. \& Jijo, S.A. 2019, "Implementing aggregate-key for sharing data in cloud environment using cryptographic encryption", International Journal of Innovative Technology and Exploring Engineering, vol. 8, no. 9 Special Issue 3, pp. 957-959.

22. Jeffrin Rajan, M., Aravindasamy, R., Kavitha, P. \& Rama, A. 2019, "A novel method of object orientation variation in $\mathrm{C}++$ and java", International Journal of Innovative Technology and Exploring Engineering, vol. 8, no. 9 Special Issue 3, pp. 708-710.

23. Nayak, R., Dinesh, S. \& Thirunavukkarasu, S. 2019, "A novel method improvement of rapid miner for the data mining applications", International Journal of Innovative Technology and Exploring Engineering, vol. 8, no. 9 Special Issue 3, pp. 457-460.

24. Sivaraman, K., Krishnan, R.M.V., Sundarraj, B. \& Sri Gowthem, S. 2019, "Network failure detection and diagnosis by analyzing syslog and SNS data: Applying big data analysis to network operations", International Journal of Innovative Technology and Exploring Engineering, vol. 8, no. 9 Special Issue 3, pp. 883-887.

25. Vimala, D., Linda, I.M. \& Priya, K.S. 2019, "Decoupling online algorithms from erasure coding in DNS", International Journal of
Innovative Technology and Exploring Engineering, vol. 8, no. 9 Special Issue 3, pp. 950-953.

26. Rama, A., Kumaravel, A. \& Nalini, C. 2019, "Preprocessing medical images for classification using deep learning techniques", International Journal of Innovative Technology and Exploring Engineering, vol. 8, no. 9 Special Issue 3, pp. 711-716.

27. Sangeetha, S., Srividhya, S.R., Anita Davamani, K. \& Amudha, S. 2019 , "A procedure for avoid overrun error in universal synchronous asynchronous receiver transmitter (usart) by utilizing dummy join and interrupt latency method", International Journal of Innovative Technology and Exploring Engineering, vol. 8, no. 9 Special Issue 3, pp 657-660.

28. Aravindasamy, R., Jeyapriya, D., Sundarajan, B. \& Sangeetha, S. 2019 , "Data duplication in cloud for optimal performance and security", International Journal of Innovative Technology and Exploring Engineering, vol. 8, no. 9 Special Issue 3, pp. 1156-1158.

29. Aravindasamy, R., Jeffrin Rajan, M., Sugumar, V. \& Kavitha, P. 2019 "A novel method on developing superblocks and the transistor using apodryal", International Journal of Innovative Technology and Exploring Engineering, vol. 8, no. 9 Special Issue 3, pp. 982-985.

30. Sasikumar, C.S. \& Kumaravel, A. 2019, "E-learning attributes selection through rough set theory and data mining", International Journal of Innovative Technology and Exploring Engineering, vol. 8, no. 10, pp. 3920-392

\section{AUTHORS PROFILE}

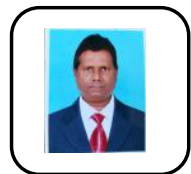

Khanaa.V Dean, Department of Information and Technology, Bharath Institute of Higher Education and Research, Chennai, India.

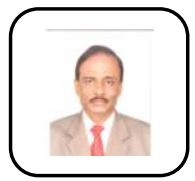

Kumaravel.A, Assistant Professor, Department of Information and Technology, Bharath Institute of Higher Education and Research, Chennai, India..

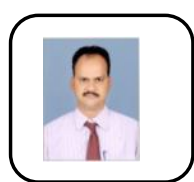

Thirunavukkarasu.S Assistant Professor, Departmen of Information and Technology, Bharath Institute of Higher Education and Research, Chennai, India 